\title{
Özel Yetenekli Öğrencilere Yönelik Destek Eğitim Odalarına İlişkin Öğretmen Görüşleri
}

\section{Serkan DEMIR* , Yunus Emre AVCU**}

Öz: Bu çalışmanın amacı, özel yetenekli öğrencilere yönelik destek eğitim odalarına ilişkin öğretmen görüşlerini belirlemektir. Nitel araştırma yöntemlerinden olgu bilim deseninin kullanıldığı bu araştırmanın örneklemini Türkiye’nin farklı şehirlerinden Milli Eğitim Bakanlığı Özel Eğitim ve Rehberlik Hizmetleri Genel Müdürlüğü tarafından “Destek Eğitim Odası Eğitici Eğitimi” üzerine düzenlenen hizmet içi eğitimine katılan toplam 76 sınıf öğretmeni oluşturmaktadır. Veri toplama aracı olarak; öğretmenlerin "Destek Eğitim Odaları" kavramına ilişkin algılarını metaforlarla belirlemek amacıyla yarı yapılandırılmış form, çizmeyazma tekniği ve odak grup görüşmesi kullanılmıştır. Elde edilen bulgular doğrultusunda öğretmenlerin destek eğitim odalarının öğrencilerin yeteneklerini ortaya çıkarıp onlara ihtiyaçları doğrultusunda uygun eğitim fırsatının sağlandığı ve bilimsel, yaratıcı ve sorgulayıcı düşünme becerilerinin kazandığı bir mekan olarak algıladıkları tespit edilmiştir.

Anahtar Kavramlar: Yazma-Çizme Tekniği, Destek Eğitim Odası, Özel Yetenekli Öğrenci, Metafor

\section{Teachers' Perceptions towards the Pull-Out Classes for Gifted Students}

\begin{abstract}
The purpose of the current study is to determine teachers' perceptions towards the pull -out classes for gifted students. The research has been designed according to
\end{abstract}

*Dr, Sınıf Öğretmeni, Beşiktaş Bilim ve Sanat Merkezi, İstanbul, serkandemir4@ gmail.com, https://orcid.org/0000-0002-2331-9861

** Şehit Prof. Dr. İlhan Varank Bilim ve Sanat Merkezi, Balıkesir, yunus1099@hotmail.com, https://orcid.org/0000-0001-8286-0837

\begin{tabular}{lll}
\hline Gönderim:09.04.2017 & Kabul:07.09.2017 & Yayın:01.02.2018 \\
\hline & 156 &
\end{tabular}


Phenomenology -a qualitive research pattern; and has been identified using criterion sampling -a purposive sampling method. The participants were 76 primary school teachers who attended in service training seminar that was held by Ministry of National Education General Directorate of Special Education and Guidance Services about Training of Trainers Course for

Pull-Out Classes. The data was collected through semi-structured interview form which aims to determine teachers' perceptions towards "pull-out classes term" by means of metaphors, drawing-writing and focus group discussion techniques. In the direction of these results of the study, the teachers regard that the pull-out classrooms which could be described as spaces where students are able to discover their abilities, provide them with appropriate training opportunities in accordance with their needs, scientific, creative and inquisitive thinking styles.

Keywords: drawing-writing technique, gifted students, metaphor, pull-out classes.

\section{Giriş}

Bilim ve Teknoloji Yüksek Kurulu'nca yayınlanan 2013 Strateji ve Uygulama Planı'nda üstün zeka kavramına karşılık kullanılması önerilen “özel yetenek” kavramı zeka, yaratıcılık, sanat veya özel akademik alanlarda akranlarına göre yüksek düzeyde performans gösteren bireyi ifade etmektedir (MEB,2013).

Milli Eğitim Bakanlığı, Bilim ve Sanat Merkezleri (BİLSEM) başta olmak üzere, "çeşitli eğitim modeli” anlayışıyla, her tür ve kademede öğrenim gören özel yetenekli öğrencilerin yetenekleri doğrultusunda kendilerini gerçekleştirmelerini sağlayacak eğitim ortamlarının hazırlanmasını ve bu ortamlarda eğitim alan öğrencilerin öğrenim hayatları boyunca gelişimlerinin takip edilmesini amaçlamaktadır (MEB 2013). Bu amaç doğrultusunda 
özel yetenekli öğrencilerin kendi akranları ile ayrıştırılmadan bulundukları okulun ve bölgenin koşullarına bağlı olarak, hafta içi ve/veya hafta sonu, yetenekleri doğrultusunda destek eğitim odalarında eğitim almaları sağlanmaktadır.

Destek Eğitim Odaları, öğrenimleri sırasında desteklenmesi gereken öğrenciler için sunulan bir eğitim hizmetidir. Okul ve kurumlarda, akranlarıyla birlikte aynı sınıfta öğrenimlerine devam eden özel yetenekli öğrenciler için özel araç-gereçler ile eğitim materyalleri sağlanarak verilen özel eğitim desteği Destek Eğitim Odası Hizmeti olarak tanımlanmaktadır. Destek Eğitim Odalarında özel yetenekli öğrencilerin potansiyelleri açığa çıkarılıp yaratıcılık, liderlik ve akademik alanlardaki yetenekleri geliştirilerek kendilerini gerçekleştirmelerine imkân sağlanacaktır.

Destek Eğitim Odalarının belirtilen bu amaçlarına ulaşılması amacıyla Özel Eğitim ve Rehberlik Genel Müdürlüğü tarafından sınıf öğretmenleri ve branş öğretmenlerine hizmet içi eğitimi kapsamında özel yeteneklilere yönelik “Destek Odaları Eğitici Eğitimi” verilmektedir. $\mathrm{Bu}$ eğitimlerdeki amaç katılımcıların özel yetenekli bireylerin eğitimlerinde kullanılabilecek eğitim modellerini uygulamalı olarak öğrenmelerini sağlamaktır. Bu eğitimi alan öğretmenler MEB tarafından formatör olarak görevlendirilmekte ve kendi il/ilçelerinde görev yapan diğer öğretmenlere eğitim vermeleri istenmektedir.

$\mathrm{Bu}$ araştırmada amaç Destek Odaları Eğitici Eğitimine katılan sınıf öğretmenlerinin, destek eğitim odalarına yönelik görüşlerinin ortaya konulması amaçlanmıştır. Noyes (2004), öğretmen eğitimi çalışmalarının en önemli noktalarından birinin de öğretmen görüşlerinin incelenmesinin olduğunu ve elde edilen sonuçların öğretmenlerin mesleki çalışmalarına ve profesyonel gelişimlerine yön vermede katkı sağlayacağını savunmaktadır. Öğretmenlerin görüşlerinin belirlenmesi sürecinde onların metaforik algılarını inceleyeretk etkili sonuç elde edilebileceği düşünülmektedir. Metaforlar, bireylerin araştırılan konuya yönelik neler 
düşündüklerini tespit etmekle beraber konuya farklı açılardan yaklaşabilmelerine de olanak sağlamaktadır (Morgan, 1998; Short, 2000). Ben-Peretz, Mendelson ve Kron (2003) da, metaforların özellikle eğitimde öğretmenlerin öğrenciler ve eğitimle ilgili düşüncelerinin altında yatanları ortaya çıkarmada etkili olduğunu savunmaktadır. Ayrıca kavramsal öğrenmeyi belirleyebilmek amacıyla öğretmenlerin sadece sahip oldukları bilgileri değil; öğretmenlerin kavramlar arasındaki ilişkilerini ve zihinlerinde oluşturdukları bilgilerle doğal dünyadaki olayların işleyişi arasındaki benzerlikleri ne ölçüde anladıklarını belirlemekte kullanılmaktadırlar. Bu kapsamda kavramlarla ilgili zihinlerindeki bilişsel yapıları ile alternatif kavramları belirlemek için yazma çizme tekniği kullanılabilir (Kurt, 2013; Patrick ve Tunnicliffe 2010; Yayla ve Eyceyurt, 2011; Zoldosova ve Prokop 2007).

Bu araştırma ile öğretmenlerin destek eğitim odalarına ilişkin görüşlerini ortaya koymak ve öğretmen görüşleri ile Milli Eğitim Bakanlığı'nın Destek Eğitim Odaları uygulamasından beklentilerinin karşılaştırılması amaçlanmaktadır. Ayrıca yazma-çizme yöntemi ile öğretmenlerin zihinlerinde oluşturdukları destek eğitim odası kavramı ile doğal dünyadaki olayların işleyişi arasındaki benzerlikleri ne ölçüde anladıklarını ortaya koymak amaçlanmaktadır.

\section{Yöntem}

Araştırma Deseni: Bu çalışmada, nitel araştırma desenlerinden araştırmanın doğasına uygun olan "olgubilim (görüngübilim, fenomenolojik) deseni" kullanılmıştır. Olgubilim deseninde amaç farkında olduğumuz, ancak derinlemesine bir anlayışa sahip olmadığımız olgulara odaklanmaktır (Yıldırım ve Şimşek, 2008).

Çalışma Grubu: Olgubilim araştırmalarında veri kaynakları araştırmanın odaklandığı olguyu yaşayan ve bu olguyu dışa vurabilecek veya yansıtabilecek bireyler ya da gruplar (Yıldırım ve Şimşek, 2008) olması gerektiğinden bu araştırmada amaçlı örnekleme yöntemi 
kullanılmıştır. Araştırma destek eğitim odası eğitici eğitimine katılan toplam 76 sınıf öğretmeni ile yürütülmüştür. Metafor çalışmasına 76 öğretmen katılmış, 76 metafor üretilmiştir. Çizmeyazma tekniği ile gerçekleştirilen çalışmaya 76 sınıf öğretmeninden 68 'i katılmış ve 68 çizim üretilmiştir. Odak grup görüşmesi ise bu öğretmenlerin arasından 6 öğretmen ile gerçekleştirilmiştir. Tablo 1.de araştırmaya katılan sınıf öğretmenlerinin demografik özellikleri sunulmuştur.

Tablo 1. Katılımcıların Demografik Özellikleri

\begin{tabular}{llll}
\hline Özellikler & & f & \% \\
\hline Cinsiyet & Kadin & 28 & 36.84 \\
\cline { 2 - 4 } & Erkek & 48 & 63.15 \\
\hline \multirow{2}{*}{ Kidem } & $1-5$ Y1l & 18 & 23.64 \\
\cline { 2 - 4 } & $6-10$ Y1 & 26 & 34.21 \\
\cline { 2 - 4 } & $11-15$ Y1l & 21 & 27.63 \\
\cline { 2 - 4 } & $15-20$ Y1l & 11 & 14.47 \\
\hline Eğitim Durumu & Lisans & 8 & 89.47 \\
\cline { 2 - 4 } & Yüksek Lisans & 8.52 \\
\hline
\end{tabular}

Verilerin Toplanması: Veri toplama aracı olarak; öğretmenlerin "Destek Eğitim Odaları" kavramına ilişkin algılarını belirlemek amacıyla yarı yapılandırılmış form, çizme-yazma tekniği ve odak grup görüşme teknikleri kullanılmıştır.

\section{Yarı Yapılandırılmış Form}

Sınıf öğretmenlerinin “Destek Eğitim Odası” kavramına ilişkin algılarını belirlemek amacıyla, öğretmenlere “Destek Ĕgitim Odaları........ gibidir. ifadelerinin yer aldı̆̆1 yarı yapılandırılmış form dağıtılmıştır. Araştırmaya katılan öğretmenlerden bir metafor üzerinde yoğunlaşmalarını ve düşüncelerini paylaşmaları için bir ders saati süre tanınmıştır. Katılımcılar verilen süre içerisinde formu teslim etmişlerdir.

\section{Çizme-Yazma Tekniği}

Bu teknik kavramlarla ilgili gizli kalmış düşünce, anlama, tutumlar hakkında ve bilişsel yapıyla ilgili görsel imajı ortaya çıkarmayı amaçlayan değerlendirme yöntemidir. (Borthwick, 
2011; Christensen ve James, 2000; Özden, 2009; Patrick ve Tunnicliffe, 2010; Zoldosova ve Prokop, 2007). Bu kapsamda katılımcıların 15 dakika içinde "Destek Eğitim Odaları kavramıyla ilgili bildiklerinizi şekille anlatınız?” sorusuna görüşlerini detaylıca ifade etmeleri istenmiştir. Şekil 1'de çizme-yazma tekniğine ait örnek sunulmuştur.

Şekil 1. Öğretmen çizim örneği

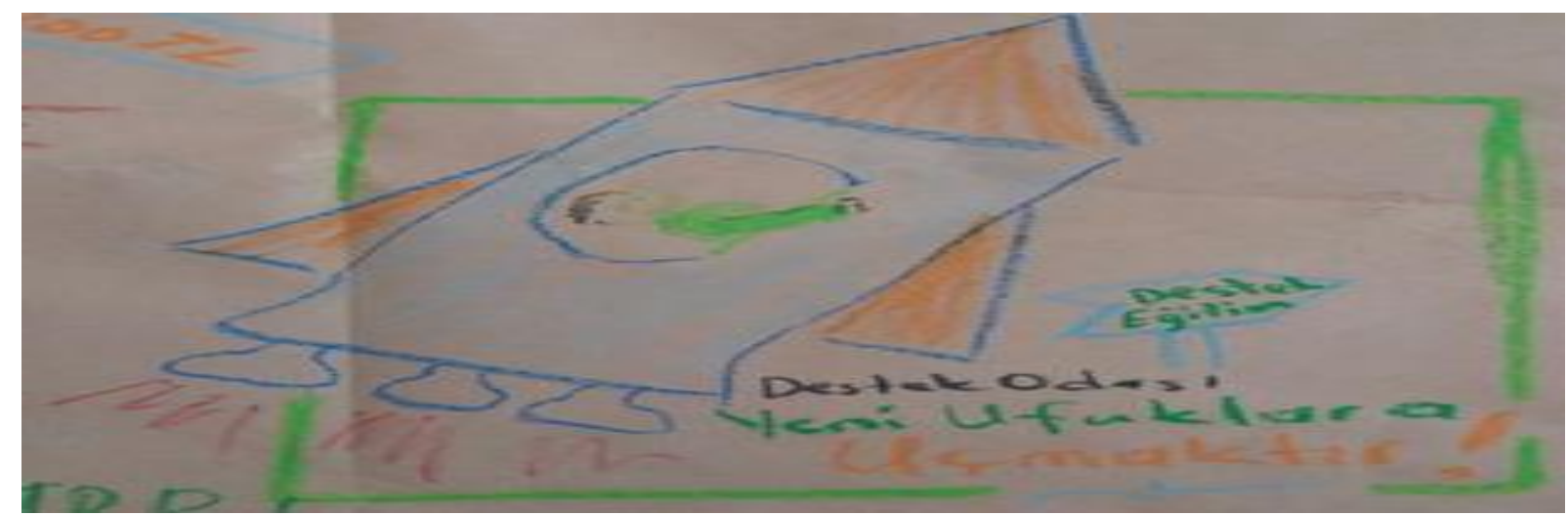

\section{Odak grup görüş̧meleri}

Odak grup görüşmesi, "Ilımlı ve tehditkâr olmayan bir ortamda önceden belirlenmiş bir konu hakkında algıları elde etmek amacıyla dikkatle planlanmış bir tartışmalar serisi” olarak tanımlanmaktadır (Yıldırım ve Şimşek, 2008). Odak grup görüşmeleri, araştırmacılar tarafından beraber yürütülmüş olup, görüşmelerde sınıf öğretmenlerinin destek eğitim odaları konusunda görüşlerini belirtmeleri istenmiştir. Katılımcıların görüşleri araştırmacılar tarafindan geliştirilmiş acık uçlu sorulardan oluşan bir görüşme formu ile toplanmıştır.

Sınıf öğretmenleri ile yapılan odak grup görüşmesine 6 öğretmen katılmıştır. Öğretmenlere;

1) Destek Eğitim Odaları hakkındaki düşünceleriniz nelerdir?

2) Destek Eğitim Odaları sizce nasıl olmalıdır?

Soruları yöneltilmiştir. Görüşme 2016 yılı A ğustos ayı içerisinde gerçekleştirilmiştir. Görüşmede yer alan sınıf öğretmenlerden 4'i lisans ve 2'i yüksek lisans mezunudur. 5 sınıf 
öğretmeni 7-15 yılları arasında, 1 sınıf öğretmeni ise 22 yıllık mesleki tecrübeye sahiptir. Odak grup görüşmesine katılan sınıf öğretmenlerinden 4'ü kadın, 2'si ise erkektir. Yarıyapılandırılırmış görüşme formu kullanılarak gerçekleştirilen odak grup görüşmesi 1 saat 47 dakika 26 saniye sürmüştür. Görüşme öncesinde ses kaydı yapılacağı öğretmenlere bildirilmiş ve bu konuda gerekli izin alınmıştır. Öğretmenler Ö1, Ö2, Ö3, Ö4, Ö5 ve Ö6 şeklinde kodlanmıştır.

Verilerin Analizi ve Yorumlanması: Araştırmada elde edilen veriler yapılan benzer araştırmalar incelenerek içerik analizine uygun olarak çözümlenmiştir. (Coşkun, 2011; Hacıfazlıŏglu, Karadeniz ve Dalgıç, 2011; Saban, 2008;). Veriler beş aşamada analiz edilmiştir. Aşamalar ve yapılan işlemler aşağıda sunulmuştur.

Kodlama ve ayıklama: Katılımciların formlarda belirttikleri metafor cümleleri Excel programına alfabetik sıraya göre girilmiştir. Metafor belirtmeyen boş formlar ve metafor belirtilmiş olsa da nedeni belirtilmeyen toplam 20 form araştırma kapsamı dışında bırakılmıştır. Katılımcıların 76 adet geçerli metafor ürettikleri belirlenmiştir.

Örnek Metafor Derleme Aşaması: Katılımcıların doldurdukları formlarda birer örnek metafor ifadesi seçilmiş ve analiz sürecinde başvuru kaynağı olarak kullanmak ve yorumları geçerli kılmak amacıyla “örnek metafor listesi” oluşturulmuştur.

Kategori Geliştirme Aşaması: Bu aşamada 76 metafor listesi baz alınarak her metafor imgesinin Destek Eğitim Odası olgusunu nasıl kavramsallaştırdığı analiz edilmiştir. Bunun için, katılımcılar tarafından belirtilen metaforlar konusu ile kaynağı arasındaki ilişki açısından analiz edilmiş olup toplam 6 farklı kavramsal kategori oluşturulmuştur.

Geçerlilik ve Güvenilirlik Aşaması: Araştırmada katılımcılar tarafından ifade edilen metaforlar öncelikle iki uzman tarafından bağımsız olarak kodlanıp kategoriler geliştirilmiştir. Daha sonra bu iki çalışma karşılaştırılarak belirlenen farklılıklar üçüncü bir uzman görüşü alınarak yeniden düzenlenmiştir. Güvenirlik hesaplanmasında 76 kavramın yer aldığı liste ile 6 
farklı kavramsal kategorinin yer aldığı liste alanda bir uzman tarafından eşleştirilmesi istenmiştir. Oluşturulan listeler karşılaştırılmış, görüş birliği ve farklılıklarının sayıları belirlendikten sonra çalışmanın güvenilirliği, Miles ve Hubermann (1994)'ın “Güvenilirlik= ((Görüş Birliği):(Görüş Birliği+Görüş Ayrllı̆gl))x 100” hesab1 kullan1larak uzman ve araştırmacıların değerlendirmeleri arasındaki uyumun \%93 olduğu tespit edilmiştir. Tespit edilen bu değer, .90 üzerinde olması güvenirliğin sağlanmış olduğunu göstermektedir (Saban; 2008).

Verilerin Bilgisayar Ortamına Aktarılması Aşaması: Bütün veriler bilgisayar ortamına aktarılarak 76 metafor ve 6 kavramsal kategoriyi temsil eden katılımcı sayısı (f) ve oranı (\%) hesaplanmıştır.

Çizme-yazma tekniğinde ise, Destek Eğitim Odası kavramıyla ilgili çizim-yazım verileri içerik analizi yöntemine göre analiz edilmiştir. Burada öğretmenlerin çizim yeteneğinin değerlendirilmesinin ötesinde destek eğitim odası kavramıyla ilgili bilişsel düzeyini ifade edebilmesi dikkate alınmıştır. Çizme-yazma tekniği ile elde edilen veriler de iki ayrı uzman tarafından bağımsız olarak kodlanarak kategoriler geliştirilmiştir. İki çalışma sonrasında karşılaştırılarak farklı olduğu düşünülen noktalar üçüncü bir uzman görüşü sonrasına revize edilmiştir. Çizme-yazma tekniği ile yapılan çalışmanın güvenirliğini hesaplamak için nitel araştırma ve nitel veri analizi konusunda uzman bir akademisyene çizimler verilerek kategorileştirilmesi istenmiştir. Uzmanın değerlendirmeleri ve araştırmacıların değerlendirmesi arasındaki uyum hesaplanmış (\% 92) ve güvenirliğin sağlandığı tespit edilmiştir.

Odak grup görüşmesinin analizi için ise yarı-yapılandırılmış görüşme formunda yer alan iki sorunun her biri kategori kabul edilmiştir. Araştırma sorularına verilen cevaplar kodlanmış, sınıflandırılarak alt kategoriler oluşturulmuş ve ilgili soru altında sunulmuştur. İki yazar da kodları ve alt kategorileri 6 katılımcı için de gözden geçirilmiş ve karşılaştırmıştır. Kodlayıcılar arasında güvenirlik hesabı yapılarak güvenirliğin sağlandığı sonucuna ulaşılmıştır. 


\section{Bulgular}

\section{Destek Eğitim Odalarına İliş̧kin Metaforlar}

$\mathrm{Bu}$ araştırmada elde edilen genel bulgulara göre, katılımcılar destek eğitim odaları kavramına ilişkin toplam 76 geçerli metafor üretmiştir. Üretilen bu metaforlar ve bunları temsil eden öğretmen sayıları (f) ve oranları (\%) Tablo 3'de sunulmuştur.

Tablo 2. Öğretmenlerin DEO kavramına ilişkin ürettikleri metaforlar

\begin{tabular}{|c|c|c|c|c|c|}
\hline Metafor & $\mathbf{f}$ & $\%$ & Metafor & $\mathbf{f}$ & $\%$ \\
\hline Ağaç & 1 & 0.76 & Maden Ocağ 1 & 2 & 1.52 \\
\hline Aile & 1 & 0.76 & Makine & 1 & 0.76 \\
\hline Akarsu & 1 & 0.76 & Malzeme Deposu & 1 & 0.76 \\
\hline Ateş & 1 & 0.76 & Matruşka & 1 & 0.76 \\
\hline Aydınlanma Odası & 2 & 1.52 & Merdiven & 1 & 0.76 \\
\hline Bambu Bitkisi & 1 & 0.76 & Nar & 1 & 0.76 \\
\hline Cankurtaran Simidi & 1 & 0.76 & NOS (Nitro Asit Sistem) & 1 & 0.76 \\
\hline Çiçek & 3 & 2.28 & Oksijen Maskesi & 1 & 0.76 \\
\hline Dershane & 1 & 0.76 & Okyanus & 4 & 3.04 \\
\hline Dışa Açılan Kap1 & 2 & 1.52 & Oyun Hamuru & 1 & 0.76 \\
\hline Dört Element & 1 & 0.76 & Özgürlük & 2 & 1.52 \\
\hline Dürbün & 1 & 0.76 & Pencere & 1 & 0.76 \\
\hline Eğitmen Kamp1 & 1 & 0.76 & Pilot & 1 & 0.76 \\
\hline Emek & 1 & 0.76 & Saat & 1 & 0.76 \\
\hline Enerji & 2 & 1.52 & Sihirbaz & 2 & 1.52 \\
\hline Farklılaştırma Ortamı & 1 & 0.76 & Sondaj Cihazı & 1 & 0.76 \\
\hline Gökkuşağ1 & 1 & 0.76 & Sonsuzluk & 1 & 0.76 \\
\hline Güneş & 4 & 3.04 & Takviye Odas 1 & 5 & 3.80 \\
\hline Hazine & 4 & 3.04 & Tren Rayı & 1 & 0.76 \\
\hline Hobi Bahçesi & 1 & 0.76 & Tuz & 1 & 0.76 \\
\hline Işsı & 1 & 0.76 & Uçak & 2 & 1.52 \\
\hline İnci & 1 & 0.76 & Ufka AydınlananYol & 1 & 0.76 \\
\hline Kaşif & 1 & 0.76 & Uzay Kapsülü & 1 & 0.76 \\
\hline Kömür & 1 & 0.76 & Vaha & 1 & 0.76 \\
\hline Laboratuvar & 1 & 0.76 & Yaşam Koçu & 1 & 0.76 \\
\hline Lehim Makinesi & 1 & 0.76 & Yetenek Geliştirme Odas1 & 4 & 3.04 \\
\hline Toplam & & & & 76 & \\
\hline
\end{tabular}

Tablo 2' de görüldüğü gibi metafordan 38'ini ( Vaha, NOS, oyun hamuru, inci, Kömür, dört element, Emek, hobi bahçesi, nar, merdiven, tren rayı, pilot, malzeme deposu, akarsu, 1ş1k, kaşif, eğitmen kampı, ufka aydınlanan yol, oksijen maskesi, yaşam koçu, bambu ağacı, dershane, lehim makinesi, uzay kapsülü, sonsuzluk, pencere, gökkuşağ1, dürbün, saat, 
matruşka, sondaj cihazı, makine, tuz, ateş, laboratuvar, cankurtaran simidi, ağaç, aile, farklılaştırma odası ) yalnızca birer katılımcı ifade etmiştir. Diğer metaforlar ise 2 ile 5 öğretmen tarafından ifade edilmiştir. Bunlar sırasıyla; takviye odası (f:5), hazine (f:4), güneş (f:4), okyanus (f:4), çiçek (f:3), yetenek geliştirme odası (f:3), enerji (f:2), aydınlanma odası (f:2), sihirbaz (f:2), maden ocağı (f:2), özgürlük (f:2), dışa açılan kapı (f:2), uçak (f:2) şeklindedir

Sınıf öğretmenlerinin destek eğitim odaları kavramına ilişkin sahip oldukları metaforlar sırasıyla; Doğa, Nesne, Soyut/Gizem, Mekan, İnsan, Bilim/Teknik olmak üzere 6 kategoride ele alınmıştır. Sınf öğretmenlerinin destek eğitim odaları kavramına ilişkin oluşturdukları metafor kategorileri tablo 3' de sunulmuştur.

Tablo 3. Öğretmenlerin DEO Kavramına İlişkin Oluşturdukları Metafor Kategorileri

\begin{tabular}{|c|c|c|c|c|c|c|}
\hline \multirow[t]{2}{*}{ Sira } & \multirow[t]{2}{*}{ Kategoriler } & \multirow[t]{2}{*}{ Metafor Adları } & \multicolumn{2}{|c|}{ Öğretmen } & \multicolumn{2}{|c|}{ Metafor } \\
\hline & & & $\mathbf{f}$ & $\%$ & $\mathbf{f}$ & $\%$ \\
\hline 1 & Doğa & $\begin{array}{l}\text { Vaha (1), Akarsu (1), Güneş (4), Okyanus (4), } \\
\text { Gökkuşağı (1), Çiçek (3), Ağaç (1), Bambu Bitkisi } \\
\text { (1) }\end{array}$ & 16 & 21.05 & 8 & 15.38 \\
\hline 2 & Soyut/Gizem & $\begin{array}{l}\text { Hazine (4), İnci(1), Özgürlük (2), Emek (1), } \\
\text { Sonsuzluk (1), Ateş (1) }\end{array}$ & 10 & 13.15 & 6 & 11.53 \\
\hline 3 & Nesne & $\begin{array}{l}\text { Oyun Hamuru (1), Kömür (1), Nar (1), Merdiven } \\
\text { (1), Tren Rayı (1), Pencere (1), Oksijen Maskesi (1), } \\
\text { Dürbün (1), Saat (1), Matruşka (1), Sondaj Cihazı } \\
\text { (1), Tuz (1), Cankurtaran Simidi (1) }\end{array}$ & 13 & 17.10 & 13 & 25.00 \\
\hline 4 & Bilim/Teknik & $\begin{array}{l}\text { Enerji (2), NOS (1), Dört Element (1), Işık(1), Kaşif } \\
\text { (1), Lehim Makinesi (1), Uzay Kapsülü (1), Uçak } \\
\text { (2), Makine (1) }\end{array}$ & 11 & 14.47 & 9 & 17.30 \\
\hline 5 & Mekan & $\begin{array}{l}\text { Aydınlanma Odası (2), Hobi Bahçesi (1), Maden } \\
\text { Ocağı (2), Malzeme Deposu (1), Laboratuvar (1), } \\
\text { Yetenek Geliştirme Odası (4), Farklılaştırma Odas } \\
\text { (1), Takviye Odası (5), Dışa Açılan Kapı (2), Eğitim } \\
\text { Kampı (1), Ufka Aydınlanan Yol (1), Dershene (1) }\end{array}$ & 22 & 28.94 & 12 & 23.07 \\
\hline 6 & İnsan & Yaşam Koçu (1), Aile (1), Pilot (1), Sihirbaz (1) & 4 & 5.26 & 4 & 7.69 \\
\hline
\end{tabular}

Doğa kategorisine yönelik: Araştırmaya katılan sınıf öğretmenlerinin 16'sı (\%21.05) tarafindan 8 metafor üretilmiştir. Üretilen bu metaforlar Vaha (1), Akarsu (1), Güneş (4), 
Okyanus (4), Gökkuşağı (1), Çiçek (3), A ğaç (1), Bambu Bitkisi (1) olarak ifade edilmiştir. Bu kategoride ifade edilen metaforlara ilişkin örnek ifadeler aşağıda sunulmuştur.

“...Destek eğitim odaları akarsu gibidir. Çünkü akarsular geçtikleri topraklara can verir. Destek eğitim odaları ülkemize can verecek..."

“...Destek eğitim odaları güneş gibidir. Çünkü ihtiyacı olanların üstüne güneş gibi parlar...” “...Destek eğitim odaları gökkuşağı gibidir. Çünkü gökkuşağının renkleri gibi rengarenk güzel aktiviteler vardır..."

Soyut/Gizem kategorisine yönelik: Araştırmaya katılan sınıf öğretmenlerinin 10’u (\%13.15) tarafından 6 metafor üretilmiştir. Üretilen bu metaforlar Hazine (4), İnci(1), Özgürlük (2), Emek (1), Sonsuzluk (1), Ateş (1) şeklinde sıralanmıştır. Bu kategoride ifade edilen kavramlara ilişkin örnek ifadeler aşağıda sunulmuştur.

“...Destek eğitim odaları emek gibidir. Çünkü özel bir eğitim gerektiren bireylerin bulunduğu ortamlarda daha fazla etkinlik, yaratıcı çalışmalar yapılır..."

“...Destek eğitim odaları özgürlük gibidir. Çünkü orada istediklerini özgürce yapabilirler ve böylelikle yaratıcılığını daha fazla gösterecektir..."

“...Destek eğitim odaları hazine gibidir. Çünkü kapağını aralayıp içine baktığımızda bir sürü cevher çıkabilir..."

Nesne kategorisine yönelik: Araştırmaya katılan sınıf öğretmenlerinin 13’ü (\%17.10) tarafindan 13 metafor üretilmiştir. Üretilen bu metaforlar Oyun Hamuru (1), Kömür (1), Nar (1), Merdiven (1), Tren Rayı (1), Pencere (1), Oksijen Maskesi (1), Dürbün (1), Saat (1), Matruşka (1), Sondaj Cihazı (1), Tuz (1), Cankurtaran Simidi (1) şeklinde sıralanmıştır. Bu kategoride ifade edilen kavramlara ilişkin örnek ifadeler aşağıda sunulmuştur. 
“...Destek eğitim odaları kömür gibidir. Çünkü bilime ve bilgiye ısıtır...”

“...Destek eğitim odaları nar gibidir. Çünkü bir bütün görünür, içini açınca her biri birbirinden farklı, içi çatlamaya hazır tohum dolu, nar tanecikleri barındırır..."

“...Destek eğitim odaları dürbün gibidir. Çünkü çok iyi göremeyene bile daha uzakları daha net gösterebilir...”

“...Destek eğitim odaları matruşka gibidir. Çünkü her seferinden içinden yeni öğeler çıkabilir..."

Bilim/Teknik kategorisine yönelik: Araştırmaya katılan sınıf öğretmenlerinin 11'i (\%14.47) tarafından 9 metafor üretilmiştir. Üretilen bu metaforlar Enerji (2), NOS (1), Dört Element (1), Işık (1), Kaşif (1), Lehim Makinesi (1), Uzay Kapsülü (1), Uçak (2), Makine (1)şeklinde sıralanmıştır. Bu kategoride ifade edilen kavramlara ilişkin örnek ifadeler aşağıda sunulmuştur.

“...Destek eğitim odaları dört element gibidir. Çünkü öğrencilerin kendini gerçekleştirmeleri için gerekli temel ihtiyaçlardır..."

“...Destek eğitim odaları lehim makineleri gibidir. Çünkü eğitimde kopmuş devreleri mutlaka birbirine lehimlemeliyiz..."

“...Destek eğitim odaları makine gibidir. Çünkü özel yetenekleri ortaya çıkarmakla yetinmeyip bunun daha değerli ve kullanışlı hale gelmesini sağlar..."

Mekan kategorisine yönelik: Araştırmaya katılan sınıf öğretmenlerinin 22'si (\%28.94) tarafından 12 metafor üretilmiştir. Üretilen bu metaforlar Aydınlanma Odası (2), Hobi Bahçesi (1), Maden Ocağı (2), Malzeme Deposu (1), Laboratuvar (1), Yetenek Geliştirme Odası (4), Farklılaştırma Odası (1), Takviye Odası (5), Dışa Açılan Kapı (2), Eğitim Kampı (1), Ufka 
Aydınlanan Yol (1), Dershane (1) şeklinde sıralanmıştır. Bu kategoride ifade edilen kavramlara ilişkin örnek ifadeler aşağıda sunulmuştur.

“...Destek eğitim odaları hobi bahçesi gibidir. Çünkü öğrenciler bu bahçenin en özel çiçeği olduğu için öğretmenlerde bu özel çiçek için özel yaşam alanı planlayıp tasarlayacaklardır..."

“...Destek eğitim odaları maden ocağı gibidir. Çünkü yer altından çıkan madenler, değerli mineraller bu tesislerde işlenerek değerlendirilir. Destek odaları da değerli öğrencileri keşfedip değerlendirir.

“...Destek eğitim odaları malzeme deposu gibidir. Çünkü öğrenci o odada kendine uygun olan malzemeyi alır..."

İnsan kategorisine yönelik: Araştırmaya katılan sınıf öğretmenlerinin 4’ü (\%5.26) tarafindan 4 metafor üretilmiştir. Üretilen bu metaforlar Yaşam Koçu (1), Aile (1), Pilot (1), Sihirbaz (1) şeklinde sıralanmıştır. Bu kategoride ifade edilen kavramlara ilişkin örnek ifadeler aşağıda sunulmuştur.

“...Destek eğitim odaları yaşam koçu gibidir. Çünkü özel yetenekli öğrencilerin hayatında karşılaşabilecekleri zorluklara çözüm yolu göstererek daha mutlu bireyler olmalarını sağlar..."

“...Destek eğitim odaları sihirbaz gibidir. Çünkü bu odalarda öğrencinin gereksinimleri olan materyal ve öğretim tekniklerini onların ihtiyaçlarına uygun hale getirebilir ..."

“...Destek eğitim odaları pilot gibidir. Çünkü kendini havada özgür hissederek istediği alanda kendini geliştirebilir...”

\section{Çizme-Yazma Tekniğiyle Elde Edilen Bulgular}

Bu bölümde öğretmenlerin destek eğitim odaları kavramıyla ilgili bilişsel yapılarına ait çizme-yazma tekniğiyle elde edilen bulgulara yer verilmektedir. Öğretmenler destek eğitim 
odalarına ilişkin algılarına yönelik 68 çizim yapmışlardır. Çizimlerden elde edilen kategori ve kodlar Tablo 5'de sunulmuşstur.

Tablo 4. DEO Kavramılla İlgili Çizme-Yazma Tekniğiyle Elde Edilen Kategori ve Kodlara Ait Bulgular

\begin{tabular}{|c|c|c|}
\hline \multirow[b]{2}{*}{ Kategoriler ve Kodlar } & \multicolumn{2}{|c|}{ Öğretmenler } \\
\hline & f & $\%$ \\
\hline \multicolumn{3}{|l|}{ Doğa } \\
\hline Y1ldı/Galaksi/Güneş/Gökkuşağı/Manzara & 10 & 15 \\
\hline Yol & 2 & 3 \\
\hline Tohum & 1 & 2 \\
\hline Volkan & 1 & 2 \\
\hline Renkli Yapraklar & 1 & 2 \\
\hline \multicolumn{3}{|l|}{ İnsan/İnsan vücudu öğesi } \\
\hline Gülen /Ağlayan/Çığlık atan yüz & 6 & 9 \\
\hline Düşünen/Sorgulayan çocuk & 4 & 6 \\
\hline Kalp & 3 & 5 \\
\hline Parmakları farklı renklerde el/Eller/El izleri & 3 & 5 \\
\hline İskelet/Eklem & 2 & 3 \\
\hline Koşan çocuk & 1 & 2 \\
\hline Beyin & 1 & 2 \\
\hline \multicolumn{3}{|l|}{ Simge/İşaret } \\
\hline Sonsuzluk işareti & 3 & 5 \\
\hline Soru işareti & 2 & 3 \\
\hline Barış işareti & 1 & 2 \\
\hline Geri dönüşüm işareti & 1 & 2 \\
\hline \multicolumn{3}{|l|}{ Teknik/Bilimsel } \\
\hline Ampul/fener/ 1ş1k aleti & 6 & 9 \\
\hline Uzay Arac1/Roket/Sıcak hava balonu/Uçuş kanadı & 4 & 6 \\
\hline Büyüteç/Teleskop & 3 & 5 \\
\hline Maden arama cihazı/detektör/kazma aracı & 3 & 5 \\
\hline Eşik/Engel & 2 & 3 \\
\hline Eğik düzlem & 1 & 2 \\
\hline Bilimsel formül & 1 & 2 \\
\hline Güneş enerjisi kondüktörü & 1 & 2 \\
\hline Atom modelleri & 1 & 2 \\
\hline Çamaşır makinesi & 1 & 2 \\
\hline Deney düzeneği & 1 & 2 \\
\hline \multicolumn{3}{|l|}{ Soyut } \\
\hline Siyah karalama içinde beyaz karalama & 1 & 2 \\
\hline Siyah karalama içinde beyaz ve kırmızı desenler & 1 & 2 \\
\hline
\end{tabular}

Tablo 5 incelendiğinde DEO hakkında öğretmenlerin çizdiği resimlerin “Doğa”, “İnsan/ İnsan vücudu öğesi”, "Simge/İşaret”, “Teknik/Bilimsel” ve "Soyut” kategorileri altında toplandığ 1 görülmektedir. "Doğa” kategorisinde öğretmenlerin \%15’i DEO’yu yıldız, galaksi, güneş, gökkuşağı ve manzara çizerek ifade etmiştir. Öğretmenlerin DEO’da öğrenim gören öğrencilerin her birinin farklı ve özel olduğunu, bir güneş gibi etraflarını aydınlattıklarını, 
birlikte ise bir galaksi, gökkuşağı ya da rengarenk bir manzara oluşturduklarını betimledikleri fark edilmiştir. Yine "Doğa” kategorisinde öğretmenlerin \%3’ü yol çizimleri yaparak yeni bir kavram olan DEO ile ilgili bir uzun bir sürece ve bu süreçte alınacak mesafeye, atılacak adımlara vurgu yapmışlardır. “İnsan/İnsan Vücudu Öğesi” kategorisinde öğretmenlerin \%9’u DEO’yu yüz ifadeleriyle ve \%6'sı ise düşünen, sorgulayan çocuk resmi ile betimlemiştir. Öğretmenler çizdikleri gülen yüzler ile DEO’da eğitim almanın özel yetenekli öğrencileri mutlu ettiğini, ağlayan yüz ile ise farklılı̆̆ının anlaşılmadığı ve bu noktada DEO'ya ihtiyacı olan öğrencileri betimlemişlerdir. Düşünen, sorgulayan çocuk resimleri ile DEO’da eleştirel ve yaratıcı düşünebilen özel yetenekli öğrencilerin eğitimine vurgu yapılmıştır. "Simge/İşaret" kategorisinde öğretmenlerin \%5'i DEO’yu sonsuzluk işareti, \%3’ü ise soru işareti ile betimlemiştir. Sonsuzluk işareti ile özel yetenekli öğrencilerin DEO’daki eğitimin sürdürülebilirliği, soru işaretleri ise yeni bir uygulama olan DEO hakkındaki akıllarda yer alan sorular resmedilmiştir. “Teknik/Bilimsel” kategorisinde öğretmenlerin \%9’u DEO’yu ampul, fener,ışık aleti çizerek, \%6'sı uzay aracı, roket, sıcak hava balonu, uçuş kanadı” çizerek ve \%5'i ise büyüteç, teleskop çizerek betimlemiştir. Ampul, fener, 1şık aleti çizerek öğretmenler DEO’ların özel yetenekli öğrencilere 1şık tuttuğunu, yol gösterdiğini betimlemişlerdir. Uzay aracı, roket, sıcak hava balonu, uçuş kanadı ile ise öğrencilerin DEO ile sınıf ortamı dışında çıktıkları öğrenme yolculuğu ve keşif süreci betimlenmiştir. "Soyut" kategorisinde ise öğretmenlerin \%2'si siyah karalama içinde beyaz karalama ve siyah karalama içinde beyaz ve kırmızı desenler çizmiştir. Bu soyut çizimlerle öğretmenler DEO’nun özel yetenekli öğrenciler için karanlıktaki umut ve 1şık olduğunu betimlemişlerdir.

Sınıf Öğretmenlerinin DEO’yu çizerek betimledikleri resimlerden birkaçı aşağıdaki gibidir: 

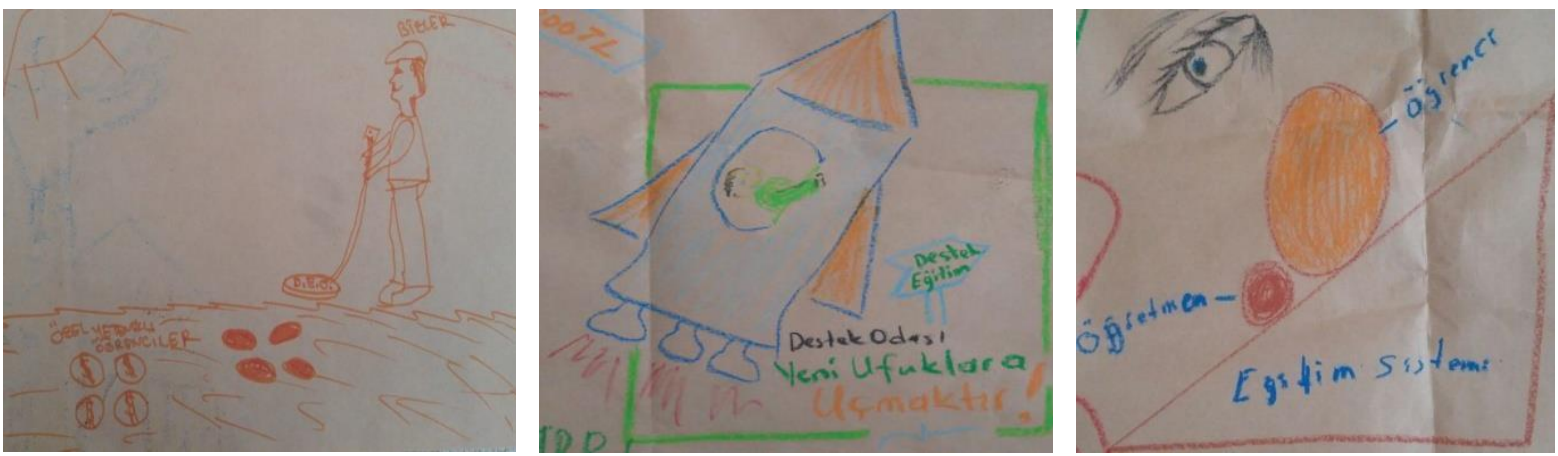

\section{Şekil 1. Öğretmen Çizimi 1}
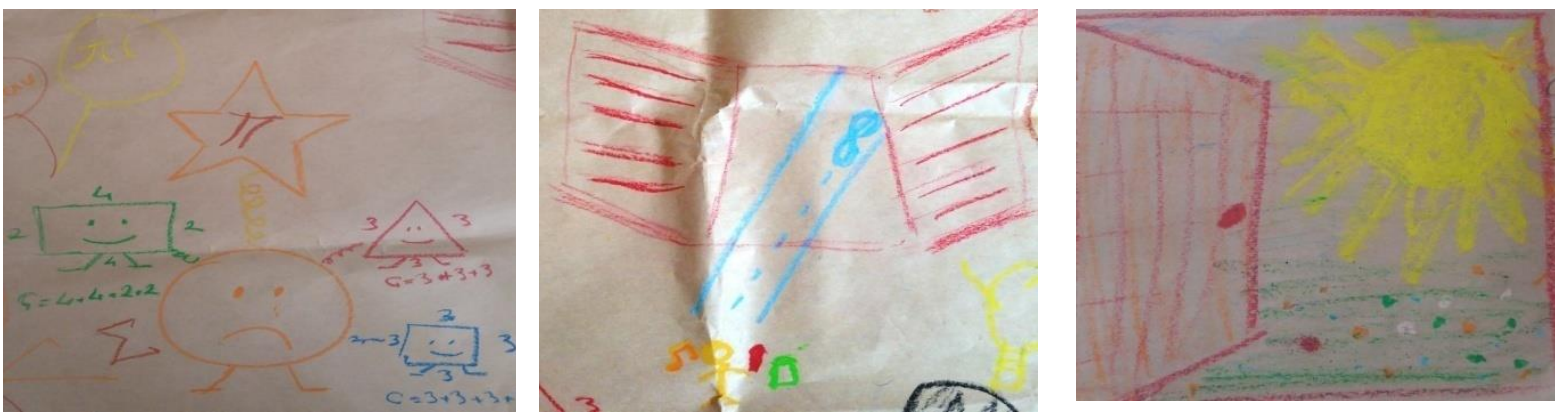

\section{Şekil 4. Öğretmen Çizimi 4 Şekil 5.Öğretmen Çizimi 5}

Şekil 6.Öğretmen Çizimi 6

\section{Odak Grup Görüşmeleri Sonucu Elde Edinen Bulgular}

Sınıf öğretmenleri ile yüz yüze yapılan odak grup görüşmesine 6 öğretmen katılmıştır. Çalışmaya katılan öğretmenlere iki soru sorulmuştur. 1. Destek eğitim odaları hakkındaki düşünceleriniz nelerdir? 2. Destek Eğitim Odaları sizce nasıl olmalıdır? Öğretmenlere sorulan bu iki soru kategori olarak kabul edilmiş, alt kategoriler ve kodlar Tablo 6 ve Tablo 7'de sunulmuştur.

Öğretmenlerin destek eğitim odalarına ilişkin görüşleri 4 alt kategori (Paydaşlara katkı, fiziksel koşullar, eğitim programı ve içeriği, korkular) altında toplanmıştır. Tablo 6'da oluşturulan alt kategori ve kodlar sunulmuştur.

Tablo 6. Öğretmenlerinin Destek Eğitim Odaları Hakkındaki Görüşleri

\begin{tabular}{lll}
\hline Alt Kategoriler ve Kodlar & Öğretmenler & \\
\cline { 2 - 3 } & f & $\%$ \\
\hline Paydaşlara Katkı & & 100 \\
\hline Öğrenci & 6 & 83 \\
\hline Ülke & 5 & \\
\hline
\end{tabular}




\begin{tabular}{|c|c|c|}
\hline Veli & 2 & 33 \\
\hline Okul & 2 & 33 \\
\hline Öğretmen & 2 & 33 \\
\hline \multicolumn{3}{|l|}{ Fiziksel Koşullar } \\
\hline Rahat hareket edilebilen/portatif masa-sandalye & 6 & 100 \\
\hline Bilgisayar/İnternet/Teknoloji & 6 & 100 \\
\hline Materyal desteği & 6 & 100 \\
\hline Bireysel eğitimine uygun & 5 & 83 \\
\hline Okul içi bir mekân & 2 & 33 \\
\hline Kitaplık & 2 & 33 \\
\hline Grup çalışmasına uygunluk & 1 & 17 \\
\hline \multicolumn{3}{|l|}{ Eğitim Programı ve İçeriği } \\
\hline Farklılaştırılmış/Zenginleştirilmiş öğretim & 6 & 100 \\
\hline Bireyselleştirilmiş eğitim plan1/Seviyeye uygun eğitim & 6 & 100 \\
\hline Ak1l oyunları & 6 & 100 \\
\hline Çalışma kâğıtları & 5 & 83 \\
\hline Merak uyandıran etkinlikler & 5 & 83 \\
\hline Yaratıcı etkinlikler & 4 & 67 \\
\hline Matematik oyunları & 4 & 67 \\
\hline Problem çözme etkinlikleri/Mantıksal yapbozlar & 4 & 67 \\
\hline Öğretim programı dışında içerik & 3 & 50 \\
\hline \multicolumn{3}{|l|}{ Korkular } \\
\hline İzolasyon/Zorbalık/Etiketlenme & 6 & 100 \\
\hline Yöneticilerin bilgi eksikliği & 6 & 100 \\
\hline Yöneticilerin DEO'lara verdiği değer & 6 & 100 \\
\hline Öğrenciyi dersten alma & 6 & 100 \\
\hline Sinıf öğretmenin olumsuz düşünceleri & 6 & 100 \\
\hline Öğretmenin ek gelir olarak görebilmesi & 6 & 100 \\
\hline Sinırlı zaman & 6 & 100 \\
\hline Sürdürülebilirlik & 4 & 67 \\
\hline Ortaokul ve lisede uygulanma zorluğu & 3 & 50 \\
\hline
\end{tabular}

Tablo 6 incelendiğinde öğretmenlerinin destek eğitim odaları hakkındaki görüşlerine yönelik olarak "paydaşlara olan katkı”, "fiziksel koşullar”, “eğitim programı ve içeriği” ve “korkular” olmak üzere dört alt kategori elde edilmiştir.

Paydaşlara katk1 alt kategorisi incelendiğinde öğretmenlerin \%100’ü destek eğitim odalarının öğrenciye olan katkısını dile getirmiştir. Bunun yanında öğretmenlerin \%83’ü destek eğitim odalarının ülkeye olan katkısını vurgulamıştır.

‘Ö3... destek eğitim odaları üstün yetenekli öğrenciye hak ettiği eğitimi sunan yerlerdir. İlgisine göre, farklılıklarına göre yani tam öğrenciye göre eğitim sunulan yerler...'

‘Ö4... destek eğitim odalarına gelen çocukların içinde belki de yeni Aziz Sancar'lar vardır. Bu ülkenin yeni Aziz Sancarlara ihtiyacı var...' 
Fiziksel Koşullar alt kategorisi incelendiğinde sınıf öğretmenlerinin \%100’ü destek eğitim odaları hakkında materyal desteğini ve teknolojik donanımı vurgulamıştır.

‘Ö1... materyal desteği sağlanan ortamlardır. Akıl oyunlarından, 3 boyutlu modellere ve kitaplara kadar çeşitli materyaller bulunmaktadır...'

‘Ö2, Ö3...görev yaptığım okuldaki destek eğitim odasında internete bağlı bir bilgisayar bulunmaktadir...'

Eğitim Programı ve İçeriği alt kategorisinde ise sınıf öğretmenlerinin \%100’ü destek eğitim odaları ile ilgili farklılaştırılmış/zenginleştirilmiş öğretimi, bireyselleştirilmiş öğretim programını/öğrenci seviyesine uygun eğitimi ve akıl oyunlarını dile getirmiştir.

'Ö6...öğrencinin ihtiyaçlarına ve ilgilerine göre içerik ve süreç farklılaştırılıyor...'

‘Ö6, Ö5... destek eğitim odalarında her öğrenci için ayrı plan yapılıyor. Planın öğrenci özelliklerine uygun olması önemli, adı üzerinde bireyleştiriyoruz...'

‘Ö1... gelen öğrenci yaşıtlarına göre önde olabiliyor. Destek eğitim odalarında çocuk kaç seviye üstteyse o seviyeye göre plan yapmak ve öğretimi bu plan çerçevesinde gerçekleştirmek önemli olan...’

‘Ö2... Destek eğitim odalarında benim çalıştığım ilde en fazla akıl oyunları var. Kalkınma ajansı ile yapılan projede bu odaların desteklenmesi kapsamında alınan araç-gereçler hep akıl oyunları idi...'

Korkular alt kategorisi incelendiğinde öğretmenlerin tamamı destek eğitim odalarında öğrenim gören öğrencilerin etiketleneceğinden, içlerine kapanabileceklerinden ve akranları tarafından zorbalığa uğrayabileceğinden söz etmiştir.

‘Ö4...haftanın belirli gün ve saatlerinde de olsa arkadaşlarının yanından ayrılan çocuğun arkadaşların ilk soracağı soru: "Nereye gidiyorsun?” oluyor. Sınıftaki arkadaşlarından üstün olduğu için ayrı bir eğitim aldığı düşüncesi çocukları yanlış davranışlara itebilir, destek eğitim odasına giden öğrenciyi de hedef gösterebilir...' 
Araştırmaya katılan öğretmenlerin destek eğitim odaları nasıl olmaları gerektiğine ilişkin görüşleri 4 alt kategori (Fiziksel ortam, Eğitim programı ve içeriği, öğretmen eğitimi, iletişim ve işbirliği) altında toplanmıştır. Tablo 7'de oluşturulan alt kategori ve kodlar sunulmuştur.

Tablo 7. Öğretmenlerinin Destek Eğitim Odalarının Nasıl Olması Gerektiğine Yönelik Görüşleri

\begin{tabular}{|c|c|c|}
\hline \multirow[t]{2}{*}{ Alt Kategoriler ve Kodlar } & \multicolumn{2}{|c|}{ Öğretmen } \\
\hline & $\mathbf{f}$ & $\%$ \\
\hline \multicolumn{3}{|l|}{ Fiziksel Ortam } \\
\hline İlgi köșesi /Tematik panolar/Öğrenme merkezleri & 6 & 100 \\
\hline Portatif mobilya & 6 & 100 \\
\hline Teknoloji/Bilgisayar/Engelsiz internet & 6 & 100 \\
\hline Zengin materyal desteği & 6 & 100 \\
\hline Hava alan sinif & 5 & 83 \\
\hline İhtiyaç bildirme sistemi & 3 & 50 \\
\hline \multicolumn{3}{|l|}{ Eğitim Programı ve İçeriği } \\
\hline Bireyselleștirilmiş Eğitim Programı & 6 & 100 \\
\hline $\begin{array}{l}\text { Yaratıcı düşünme/Eleştirel düşünme/Analitik düşünme } \\
\text { Etkinlikleri }\end{array}$ & 6 & 100 \\
\hline Mühendislik/ STEM/ Tasarım & 6 & 100 \\
\hline Gezi/Gözlem/Araştırma İnceleme & 5 & 83 \\
\hline Farklılaştırılmış/Zenginleştirilmiş/Zorlayıcı öğretim & 4 & 67 \\
\hline \multicolumn{3}{|l|}{ Gelecek problemleri çözme (Future Problem Solving)/ } \\
\hline Yaratıcı problem çözme/ Yaratıcı düşünme etkilikleri & 3 & 50 \\
\hline Yarışmalar/Fuarlar/Sergiler & 3 & 50 \\
\hline Proje tabanlı öğrenme/ E-twinning projeleri & 3 & 50 \\
\hline Sanat & 2 & 33 \\
\hline Robotik & 2 & 33 \\
\hline \multicolumn{3}{|l|}{ Öğretmen Eğitimi } \\
\hline Hizmet içi eğitim/Uygulamalı eğitim & 6 & 100 \\
\hline Yüksek lisans programları & 6 & 100 \\
\hline Lisans dersleri & 4 & 67 \\
\hline Uzaktan eğitim & 2 & 33 \\
\hline ECHA (Avrupa Üstün Yetenek Konseyi) Sertifikas1 & 1 & 17 \\
\hline \multicolumn{3}{|l|}{ İletişim ve İşbirliği } \\
\hline $\begin{array}{l}\text { DEO' da çalışan öğretmen-sınıf öğretmeni-idare- } \\
\text { rehberlik servisi arası iletişim }\end{array}$ & 6 & 100 \\
\hline Diğer kurumlarla (BİLSEM/RAM/MEB) İletișim & 5 & 83 \\
\hline Veli eğitimi/Veli işbirliği & 5 & 83 \\
\hline Uzman desteği & 4 & 67 \\
\hline Sivil toplum işbirliği & 3 & 50 \\
\hline
\end{tabular}

Sınıf öğretmenlerinin destek eğitim odalarının nasıl olması gerektiğine yönelik görüşleri olarak görüşlerinin yer aldığı Tablo 7 incelendiğinde "fiziksel ortam”, “eğitim programı ve içeriği", “öğretmen eğitimi” ve "iletişim ve işbirliği” olmak üzere dört alt kategoriye ulaşılmıştır. 
Fiziksel ortam alt kategorisinde sınıf öğretmenlerinin tamamı destek eğitim odalarında ilgi köşeleri, tematik panolar, öğrenme merkezleri, portatif mobilyaların ve teknoloji desteğinin olması gerektiğinden söz etmiştir.

‘Ö4...üstün yetenekli öğrencilerin değişik ilgi alanları oluyor. Örneğin uzay ya da ilginç canlılar. Bu ve benzeri konulara yönelik destek odalarında köşeler oluşturulabilir...'

‘Ö2...sabit durmayı sevmediklerinden hareketli sandalye ve masa olmalı. Üç öğrenci olan gruplar da var, bu gruplarda çeşitli etkinliklerde sınıf ortamı değiştirebilmeli...'

Eğitim programı ve içeriği alt kategorisi incelendiğinde sınıf öğretmenlerinin tamamı tarafından destek eğitim odalarında öğrenciler için bireyselleştirilmiş öğretim planı hazırlanması, yaratıcı, eleştirel ve analitik düşünme becerilerinin geliştirilmesi ayrıca STEM, mühendislik, tasarım eğitimi üzerinde durulmuştur.

‘Ö5...ilk önce bireyselleştirilmiş öğretim planı hazırlanmalı. Bu bir nevi yol haritası oluyor...’ ‘Ö6...destek odalarında üst düzey düşünme becerileri desteklenmeli. Bunların başında yaratıcılık geliyor. Aynı zamanda kanıta dayalı düşünme ve mantıksal çıkarımda bulunmayı da öğretmek lazım...’

Öğretmen eğitimi alt kategorisi incelendiğinde öğretmenlerin tamamı destek eğitim odalarında görev alan veya alacak öğretmenlerin teorik ve uygulamalı hizmet içi eğitime katılması gerektiğinden ayrıca üstün yetenekli öğrencilerin eğitimi alanında yüksek lisans yapmış öğretmenlerin öncelikle görevlendirilebileceği üzerine görüşlerini belirtmişlerdir.

‘Ö1...biz bakanlığın 100 saatlik bir hizmet içi eğitime katıldık. Eğitimde uygulamalı atölyeler de vardı. Kesinlikle görev alacakların bu eğitimi alması gerekir...'

‘Ö2...öğretmenlerin üstün zekâlı çocukların eğitimiyle ilgili yüksek lisans programlarına girişi kolaylaşmalı ve bu programlardan mezun olanlara öncelik verilmeli...'

İletişim ve işbirliği alt kategorisinde ise destek eğitim odasında görev alan öğretmenlerin diğer öğretmenler, rehberlik servisi ve okul idaresi ile iletişim kurulması 
gerektiği görüşlerine başvurulan tüm sınıf öğretmenleri tarafından dile getirilmiştir. Bunun yanında diğer kurumlarla iletişim kurulması gerektiği vurgulanmıştır.

Ö6‘ ...sınıf öğretmeni ders işlerken öğrenciyi destek eğitim odasına almak çok zor. Bu noktada sınıf öğretmeni ile olan iletişim her şeyden önemli, kendimizi sınıf öğretmenine iyi anlatmak zorundayı...'

Ö3‘...çalıştığımız ilde bilim ve sanat merkezleri varsa ihtiyaç olunan konularda yardım istenebilir...'

\section{Tartışma ve Sonuç}

Öğretmenlerin destek eğitim odalarına ilişkin algılarını belirlemek amacıyla yarı yapılandırılmış form, bilişsel yapılarını belirlemek amacıyla çizme yazma yöntemi ve düşüncelerini oraya koymak amacıyla yapılan odak grup görüşmeleri ile toplanan verilerin analizi sonucunda birbirini destekler şekilde oldukça detaylı ve zengin veri elde edilmiştir. Bu kapsamda elde edilen metaforlar 6 kategori altında toplandığı belirlenirken ( Doğa, Nesne, Soyut/Gizem, Mekan, İnsan, Bilim/Teknik), çizme yazma tekniğiyle de 5 kategori (Doğa, İnsan/ İnsan vücudu öğesi, Simge/İşaret, Teknik/Bilimsel ve Soyut) belirlenmiştir. Bu durum her iki teknik sonunda benzer bulguların elde edildiğini göstermektedir. Kategoriler incelendiğinde öğretmenlerin en fazla mekan kategorisinde metafor ürettikleri ve çizme yazma yöntemi ile de teknik/bilimsel kategorisinin baskın olduğu tespit edilmiştir.

Öğretmenler tarafından üretilen metaforlardan elde edilen bulgular doğrultusunda mekan kategorisinin baskın olduğu tespit edilmiştir Öğretmenler destek eğitim odalarının öğrencilerin yeteneklerinin geliştirildiği (yetenek geliştirme odası f:4), öğrencilerin ihtiyaç duydukları eğitim konusunda desteklendiği (takviye odası f:5), destek eğitim odaları ile sınıf dışında çıktıkları öğrenme yolculuğu ve keşif süreci (dışa açılan kapı f:2; ufka aydınlanan yol f:1) olarak algıladıkları tespit edilmiştir. Ayrıca öğretmenler tarafından üretilen metaforlar incelendiğinde destek eğitim odalarının bir hazine gibi saklanmış yeteneklerin ortaya 
çıkarıldığı, okyanus gibi sınırları geniş bir alanda öğrencilerin eğlenerek, özgürce kendilerini geliştirdiği alanlar olarak algıladıkları tespit edilmişstir.

Araştırma kapsamında kullanılan çizme yazma yöntemi ile elde edilen bulgular doğrultusunda öğretmenlerin destek eğitim odalarında öğrenim gören öğrencilerin her birinin farklı ve özel olduğunu, bir güneş gibi etraflarını aydınlattıklarını, birlikte ise bir galaksi, gökkuşağı ya da rengarenk bir manzara oluşturduklarını betimledikleri tespit edilmiştir. Yine "Doğa" kategorisinde öğretmenler yol çizimleri yaparak yeni bir kavram olan destek eğitim odaları ile ilgili bir uzun bir sürece ve bu süreçte alınacak mesafeye, atılacak adımlara vurgu yaptıkları belirlenmiştir. Düşünen, sorgulayan çocuk resimleri ile destek eğitim odalarında eleştirel ve yaratıcı düşünebilen özel yetenekli öğrencilerin eğitimine vurgu yapılmıştır.

Öğretmenlerin destek odalarını sonsuzluk işareti ve soru işareti ile betimledikleri sonsuzluk işareti ile özel yetenekli öğrencilerin destek eğitim odalarındaki eğitimlerinin sürdürülebilirliği, soru işaretleri ise yeni bir uygulama olan destek eğitim odaları hakkındaki akıllarda yer alan sorular resmedilmiştir. Bedur, Bilgiç ve Taşlıdere (2015) özel yetenekli öğrencilere destek eğitim odalarında verilen eğitimin mevcut durumunu ortaya çıkarmak için yaptıkları çalışmalarında destek eğitim hizmetinin başlamış olmasına rağmen bazı eksiklerinin olduğunu tespit etmişlerdir. Özel yetenekli öğrencilere sunulan destek eğitim odası hizmetinin yeni bir uygulama olması nedeniyle öğretmenlerin akıllarında birtakım soru işaretlerinin ve hizmetin sürdürülebilirliğiyle ilgili kuşkuların olmasının doğal olduğu düşünülmektedir. Öğretmenlerin destek eğitim odalarına ilişkin ampul, fener, 1şık aleti çizerek özel yetenekli öğrencilere destek eğitim odalarının 1şık tuttuğunu, yol gösterdiğini betimlemişlerdir. Uzay aracı, roket, sıcak hava balonu, uçuş kanadı ile ise öğrencilerin destek eğitim odaları ile sınıf ortamı dışında çıktıkları öğrenme yolculuğu ve keşif süreci olarak betimlenmiştir. 
$\mathrm{Bu}$ araştırma kapsamında yapılan odak grup görüşmeleri sonunda öğretmenlerin tamamı destek eğitim odalarının en çok öğrencinin kendi gelişimine ve ülkemize olan katkılarını dile getirmiştir. Eğitim programı ve içeriği kategorisinde ise sınıf öğretmenlerinin tamamı destek eğitim odaları ile ilgili farklılaştırılmış ve zenginleştirilmiş öğretimi, bireyselleştirilmiş öğretim programını ve akıl oyunlarını dile getirmiştir. Sak (2014) destek eğitim oda uygulamalarında çoğunlukla zekâ atölyelerine ve akıl oyunları türündeki etkinliklere yer verildiğini belirtmektedir. Ayrıca bu araştırmada, sınıf öğretmenlerinin tamamı tarafından destek eğitim odalarında öğrenciler için yaratıcı, eleştirel ve analitik düşünme becerilerinin geliştirilmesi ayrıca STEM, mühendislik, tasarım eğitimi üzerinde durulmuştur. Özel yetenekli öğrencilerin eğitimlerinde zekâ alt becerilerini, yaratıcılıklarını düşünme becerilerini, bilime karşı merak bilgilerini, sanat, spor gibi alanlara yönlenmelerini sağlayıcı, geleceğin trendi olacak teknolojik yeterlikleri geliştirici eğitimlerin verilmesi tavsiye edilmektedir (Tortop, 2015)

Öğretmenlerle yapılan görüşmelerde öğretmenlerin destek eğitim odalarında öğrenim gören öğrencilerin etiketleneceğinden, içlerine kapanabileceklerinden ve akranları tarafından zorbalığa uğrayabileceğinden söz etmiştir. Ayrıca destek eğitim odalarına yönelik olarak yöneticilerin bilgi eksikliklerinin olması ve destek eğitim odalarına yöneticilerce verilen değerin öğretmeleri korkuttukları belirtilmiştir. Öğretmenlerin destek eğitim odalarına yönelik bir diğer görüşü de haftanın belirli günlerinde belirli ders saatlerinde öğrencinin dersten alınması noktasında ortaya çıkmıştır. Bu noktada öğrencileri derslerinden alıp destek eğitim odalarında eğitime almanın sınıf öğretmenlerince olumsuz karşılandığı belirtilmiştir. Bu bulgu Sak (2014) ve Şahin (2015) tarafından da desteklenmektedir. Sak (2014) ve Şahin (2015) destek eğitim odası uygulamasının başarılı olmasının sınıf öğretmeni ile destek eğitim odasında görev alan öğretmen arasındaki iyi iletişime ve işbirliğine bağlı olduğunu belirtmektedir. Aksi takdirde öğretmenler destek eğitim odalarına giden öğrencilerin önemli etkinlikleri 
kaçırdıklarını ve derslerinden geri kaldıklarını öne sürerek öğrencilerin destek eğitim odasına gitmelerine karşı çıkabilirler.

Araştırmaya katılan öğretmenler destek eğitim odalarında öğrencilerin ilgi, ihtiyaç ve gelişimlerine uygun materyallerle beraber teknoloji desteğinin olması gerektiğini ve destek eğitim odasında görev alan öğretmenlerin diğer öğretmenler, rehberlik servisi ve okul idaresi ile iletişim kurulması gerektiğini savunmaktadırlar. Nar ve Tortop (2017) tarafından yapılan araştırmada da öğretmenler destek eğitim odaları içerisinde uygulamaların olması ile beraber etkinlik geliştirme eğitimleri, odalardaki eğitim sürelerinin uzatılması ve üniversitelerden destek alınması gibi öneriler sunmuşlardır. Destek eğitim odalarının geliştirilmesi için ihtiyaçların giderilmesi konusunda isteklerini belirtmişlerdir. Bu odalarda görev yapacak öğretmenlerin sınıflarından bağımsız olarak çalışması gibi önerilerde bulunmuşlardır.

\section{Makalenin Bilimdeki Konumu (Yeri)}

Özel yetenekli öğrencilerin eğitimi, Destek eğitim odalarına ilişkin görüşleri

\section{Makalenin Bilimdeki Özgünlüğü}

Bu araştırmada amaç Özel Eğitim ve Rehberlik Genel Müdürlüğü tarafından düzenlenen Özel Yeteneklilerde Destek Odası Eğitici Eğitimine katılan sınıf öğretmenlerinin, Destek Eğitim Odalarına yönelik görüşlerini ortaya konulması amaçlanmıştır. Noyes (2004); öğretmen görüşlerinin incelenmesiyle, öğretmen eğitimi konusunda yapılacak çalışmalara yön vermede katkı sağlayacağını savunmaktadır.

Bu araştırma ile öğretmenlerin destek eğitim odalarına ilişkin görüşlerini ortaya koymak ve öğretmen görüşleri ile Milli Eğitim Bakanlığı'nın Destek Eğitim Odaları uygulamasından beklentilerinin karşılaştırılması amaçlanmaktadır. Ayrıca yazma-çizme yöntemi ile öğretmenlerin zihinlerinde oluşturdukları destek eğitim odası kavramı ile doğal dünyadaki olayların işleyişi arasındaki benzerlikleri ne ölçüde anladıklarını ortaya koymak amaçlanmaktadır. 
$\mathrm{Bu}$ araştırmanın özgün olmasının nedenlerinden biri de öğretmen görüşlerinin belirlenmesinde metafor, çizme-yazma tekniği ve odak görüşmeler yapılarak veri çeşitliliğinin arttırılmasıdır. Konu ile ilgili yapılan çalışmalarda her üç tekniğin bir arada kullanıldığı başka bir çalışmaya rastlanılmamıştır.

\section{Kaynakça}

Bedur, S., Bilgiç, N., Taşlıdere, E. (2015). Özel (Üstün) Yetenekli Öğrencilere Sunulan

Destek Eğitim Hizmetlerinin Değerlendirilmesi. Hasan Ali Yücel Eğitim Fakültesi Dergisi, 12(23), 159-175.

Ben-peretz, M., Mendelson, N., Kron, F.W. (2003). How teachers in different educational context view their roles. Teaching and Teacher Education, 19, 277-290.

Borthwick, A. (2011). Children's perceptions and attitudes towards their mathematics lessons. In C. Smith, (Ed.), British Society for Research into Learning Mathematics, 31, 37-42.

Christensen, P., \& James, A. (2000). Research with Children. London: Falmer Press.

Coşkun, M. (2011). Lise Öğrencilerinin “İklim” Kavramıla İlgili Metaforları. Turkish Studies International Periodical For the Languages, Literature and History of Turkish or Turkic, 5 (3), 919-940.

Hacıfazlıoğlu, Ö., Karadeniz, Ş., Dalgıç, G. (2011). Okul Yöneticilerinin Teknoloji Liderliğine İlişsin Algıları: Metafor Analiz Örneği. Eğitim Bilimleri Araştırmaları Dergisi, 1 (1), 97-121

Kurt, H. (2013). Biology student teachers' cognitive structure about "Living thing". Educational Research and Reviews, 8 (12), 871-880. 
YYÜ Ĕ̈itim Fakültesi Dergisi (YYU Journal of Education Faculty), 2018; 15(1):156-185, http://efdergi.yyu.edu.tr

MEB.(2013). Özel Yetenekli Bireylerin Eğitimi Strateji ve Uygulama Klavuzu. Özel Eğitim

Rehberlik Hizmetleri Genel Müdürlüğü. Ankara. orgm.meb.gov.tr adresinden 14.08.2016 tarihinde indirilmiştir.

MEB.(2015). Destek eğitim odası açılması. Genelge 2015/15. Milli Eğitim Bakanlığı Özel Eğitim ve Rehberlik Hizmetleri Genel Müdürlüğü. Ankara.

Miles, M.B., Huberman, A.M. (1994). Qualitative Data Analysis. Thousand Oaks, CA: Sage Publications

Morgan, G. (1998). Yönetim ve Örgüt Teorilerinde Metafor. İstanbul: MESS Yayınları.

Nar, B., Tortop, H.S. (2017). Üstün/Özel Yetenekli Öğrencilere Yönelik Destek Eğitim Odas1 Uygulaması: Sınıf Öğretmenlerinin Öz Yeterlikleri Ve Görüşleri. Üstün Zekâlılar Eğitimi ve Yaratıcılık Dergisi, 4(1), 1-24

Noyes, A. (2004). Producing Mathematics Teachers: A sociological perspective. Teaching Education, 15 (3), 243-256.

Özden, M. (2009). Primary student teachers' ideas of atoms and molecules: Using drawings. Education, 129(4), 635-642.

Patrick, P. G., \& Tunnicliffe, S. D. (2010). Science Teachers' drawings of what is inside the human body. Journal of Biological Education, 44 (2), 81-87.

Saban, A. (2008). Okula İlişkin Metaforlar. Kuram ve Uygulamada Ĕ̆itim Yönetimi Dergisi, $55,459-496$.

Sak, U. (2014). Üstün Zekâlılar Özellikleri Tanılanmaları Eğitimleri. Ankara: Vize Yayıncılık. 
Short, C. D. (2000), Analysing metaphor in human resource development, Human Resource Development International, 3(3), 323-341.

Şahin, F. (2015). Üstün Zekâlı Öğrencilerin Ĕ̆itimine Yönelik Eğitsel Stratejiler. Feyzullah Şahin (Ed.), Üstün Zekâlı ve Üstün Yetenekli Öğrencilerin Eğitimi içinde (s.1-14). Ankara: Pegem Akademi.

Tortop, H. S. (2015). Üstün zekâlılar ĕgitiminde farklılaştırılmış ögretim müfredat farklılaştırma modelleri. Düzce: Genç Bilge Yayıncılık.

Yayla, R. G., \& Eyceyurt, G. (2011). Mental models of pre-service science teachers about basic concepts in chemistry. Western Anatolia Journal of Educational Sciences, 2011, 285-294

Yıldırım, A. ve Şimşek, H. (2008). Sosyal Bilimlerde Nitel Araştırma Yöntemleri. Ankara: Seçkin Yayıncılık.

Zoldosova, K., \& Prokop, P. (2007). Primary pupils” preconceptions about child prenatal development. Eurasia Journal of Mathematics, Science \& Technology Education, 3(3), 239-246.

\section{Extended Abstract}

\section{Problem Statement}

The importance given to special education in the World and Turkey has increased in conjunction with the developments and innovations in general education. Gifted education in Turkey has undergone dramatic changes in recent years. Innovations and regulations in the education of gifted and talented students have emerged and been formed as a result of a global agenda of the country. New steps such as the establishment of science high schools have been 
taken at specific critical point in history. With the beginning of the 21 st century, the education of gifted students has gained momentum with the national strategic plan on gifted education and establishment of gifted education departments in universities. In the last fifteen years, the number of special programs and scientific publications has multiplied.

\section{Purpose of the Study}

The purpose of the current study is to determine teachers' perceptions towards the pull-out classes for gifted students. The research has been designed according to phenomenology-a qualitive research pattern; and has been identified using criterion sampling-a purposive sampling method.

\section{Methods}

In this study, interviewing method on phenomenological design within the framework of qualitative research was used. Research was carried out working group consisting of 76 primary school teachers. The working group was created having a specified goal sampling method. In this study, the data were obtained through interviews method. The data were obtained using the main form of the interview as a means of data collection. The data were analyzed through content analysis in the qualitative research. Data analysis is to determine the experiences and meanings in the phenomenological research design. For this purpose, in the content analysis was aimed to reveal conceptualization of the data and themes that identify cases.

Participants are 76 primary school teachers who attended in service training seminar that is held by Ministry of National Education General Directorate of Special Education and Guidance Services about Training of Trainers Course for Pull-Out Classes. The data was collected through semi-structured interview form in which aims to determine teachers' perceptions towards "pull-out classes term" by means of metaphors, drawing-writing technique and focus group discussion. The form in which contains sentences as "Pull-out classes are like... Because..." and "Pull-out classes should be like... Because..." was given to the teachers in order to determine the perceptions towards the pull-out classes for gifted students. By using drawing-writing technique, teachers were asked to tell their opinions in detail based on the question as "How do you tell us what you think about pull-out classes by drawing?". The focus group discussion with the semi-structured interview form was conducted with 6 participants. The interview lasted approximately 2 hours. 
In the end of the current study which aims to determine teachers' perceptions by means of semistructured form and metaphors towards "pull-out classes term", the detailed and rich data which supports each other have been reached by means of content analysis. The metaphors teachers generated were analyzed using the following five steps:1)coding and elimination, 2)sorting and categorization, 3)validity and reliability, 4)analyzing data quantitatively, 5)constructive analysis technique. In coding and elimination step, all the metaphorical images supplied by the participants were coded. Forms, in which a metaphorical image was not clearly articulated, a rationale was not provided or peculiar explanations were written, were eliminated. In sorting and categorization stage, generative categories were tried to be defined out of 76 surface metaphors.

In this stage each metaphorical image was analyzed to characterize its elements. In order to assure validity and reliability of the study intercoder reliability and Miles and Huberman's (1994) inter coder reliability formula was used. In the next step, all the study data were entered into the SPSS program to calculate the frequencies (f) and percentages (\%) of the metaphorical images in each conceptual category.

\section{Finding and Discussions}

The data collected through the metaphors were divided into 5 categories (Nature, Objects, Abstract/Mystery, Place, People, Science/Technical) and the data collected through drawingwriting technique were divided into 5 categories (Nature, People/Part of Human Body, Sign/Symbol, Technical/Scientific and Abstract) as well. This states that the similar findings have been achieved by means of these two techniques. When the categories have been examined, it has been reached that teachers created metaphors mostly in place category and technical/scientific category is dominant among the other categories when analyzing the data gathered by drawing-writing technique.

\section{Conclusions and Recommendations}

According to the findings, it has been reached that teachers perceive pull-out classes as a place in which is found students' abilities out and provided appropriate instructional opportunities meet their needs. Teachers also perceive pull-out classes as a learning journey and discovering process in which they have thank to scientific, creative and inquiry based thinking. 
In the end of the focus group discussion, 4 categories have been reached about the ideas of primary school teachers for pull-out classes as "contribution to stakeholders", "physical features", "curriculum and context" and "fears". In the contribution to stakeholders' category, all teachers mostly stated the contributions of pull-out classes to students' personnel development and to the country. In the curriculum and context category, all teachers stated differentiated and enriched instruction, individualized education program and mind games. Also, it has been accentuated by all the primary school teachers that developing creative, critical and analytical thinking skills in pull-out classes 